\title{
OPTIMAL INTERNATIONAL FINANCIAL COOPERATION : SOLUTION TO THE GROWING BREAKDOWN OF GLOBAL COOPERATION
}

\author{
Chairuddin Syah Nasution \\ Bhayangkara Jakarta Raya University
}

\begin{abstract}
International Financial Cooperation today may require a more complex preparation than ever, particularly in the era of globalization. It is known that the global economy may bring about changing socio-economic, cultural, technological, and political condition of many countries, whilst the globalization itself has often surpassed domestic circumstances among nations which consequently leads to the need of providing a more advance principles of international financial cooperation. Regardless to these changing circumstances, the international financial cooperation may differ in nature which relatively depends on the types and objectives of the international institution involved. On the other sides, the literatures on international policy coordination are vast and multifaceted (there is no one size fits for all). However, there are some basic conditions that can be shared in common. Based on the study of various literatures, it is found that the challenges of international financial cooperation today may encircle not only about the readiness of the nation states, institutions, and related projects in utilizing the international financial cooperation, but it may also include other variuos aspects such as an optimal structure of cooperation agreement, a pattern of compliance with cooperation agreements, principles for cross border cooperation on crisis management, sharing rules of the costs of future interventions, and perhaps specific issues and barriers. All of these challenges and barriers certainly need coordinated actions to ensure that the optimal objectives of the international financial cooperation are achieved. Thus, these pre-requisite conditions should be embraced in the more advance guiding principles of the international financial cooperation. As such, the relevant authorities, including supervisory agencies, central banks, and finance ministries will also be able to tackle a severe stress in case of sudden financial crisis and managing them successfully.
\end{abstract}

Keywords : optimal, financial, global, cooperation, crisis, solution. 


\section{BACKGROUND}

\section{INTRODUCTION}

Hale., et al (2013), in his article "Gridlock : The growing breakdown of global cooperation" stated that global cooperation today is facing gridlocked across a range of issue areas". Hale., et al, explained further that The reasons for the gridlock are not the result of any single underlying causal structure, but rather of several underlying dynamics that work together. Global cooperation today is failing not simply because it is very difficult to solve many global problems but also the multi polarity has caused a global problem cannot be adequately addressed. While, the institutional inertia has created the conditions under which a multitude of actors could benefit from forming multinational companies, investing abroad, developing global production chains, and engaging with a plethora of other social and economic processes associated with globalization. These conditions, combined with the expansionary logic of capitalism and basic technological innovation, changed the nature of the world economy, radically increasing dependence on people and countries from every corner of the world. This interdependence, in turn, created demand for further institutionalization, which states seeking the benefits of cooperation provided, beginning the cycle anew.

Thus, the arrangement of international financial cooperation may no longer encircle around the prudent use of the financial itself such as loan funds, financial aids and other form of financial cooperation and effective debt management, but it should also include an optimal structure of cooperation agreement that optimize benefits of the international financial cooperation for each party involved, a pattern of compliance with cooperation agreement, principles for cross border cooperation on crisis management, sharing rules of the costs of future interventions, and perhaps specific issues and barriers which need coordinated action that may arise in handling severe stress that may happen during the period of financial cooperation beside sharing information where ever necessary and possible, and to ensure that 
financial cooperation develop adequate contingency plans. In addition, the issue of foreign debt and its impact on human rights and development and sound risk governance practices must also be taken into consideration.

It is true that the international financial cooperation may differ in nature, depends on the types of the financial institution involved and the objective of the cooperation, while the literature on international policy coordination is vast and multifaceted (there is no one size fits for all). However, there are some basic conditions that can be shared in common.

Aware to such phenomena, a more advance international financial cooperation is a must if countries involved in the cooperation want to achieve optimum benefits, otherwise only one country gain benefits at the expense of others. Therefore an analysisregardinganoptimalinternational cooperation deems relevant with the objective of finding the common basic priciples that can help improve the future financial cooperation and provide solution to the growing breakdown of global cooperation. This research is based on various literature studies which aimed at finding the universalities of the international financial cooperation.

\section{LITERATURE STUDIES}

\section{Domestic Conditionality In International Cooperation}

Svolik. (2004), stated that. An international financial cooperation agreement between governments that cannot perfectly observe their domestic circumstances reconciles a trade-off between political efficiency of international cooperation andincentives to misrepresent domestic circumstances. The possibility that some governments would misrepresent their domestic circumstances in order to achieve a more favorable cooperation outcome leads to the inability of reaching efficient cooperation outcomes in a range of plausible scenarios. Therefore, he suggested that

there are two central aspects of international cooperation that must be taken into consideration: (1) the optimal structure of international cooperation agreements 
which can perfectly provideoptimum advantages for domestic circumstances, and (2) the pattern of compliance with international cooperation agreements which determines commitmentlevels,avoidingconsequencesofviolation/risks, and high quality of monitoring capability.

\section{The New Feature Of Crisis Today}

Niepmann and Eisenlohr. (2011), observed that the new feature of crises today is that they are rarely local and often involve banks and consumers worldwide. Two aspects of financial globalization have been driving this features. First, the balance sheets offinancial institutions have become increasingly linked internationally. As a result, a crisis can spread rapidly from the financial sector of one country to other countries - a phenomenon known as 'contagion'. Second, there has been a steep rise in cross-border banking. In a world of global finance, investors from many different countries are directly affected when a bank is in distress. This poses new challenges for policy-makers responding to financial crises. Their decisions have effects both at home and abroad. At the same time, domestic economic outcomes often depend on interventions by foreign governments. The recent financial crisis has shown how this international dimension to policy interventions can lead to conflicts of interest between countries. Thus, if governments do not cooperate when dealing with an international crisis but instead behave strategically, this can lead to decisions that are 'sub-optimal' from a global perspective. Different institutional arrangements that allow governments to cooperate within well specified rules could address this concern and improve global crisis management.

\section{Beneficial Cooperation Between Government}

Studies by Freixas., et al (2011) have made the case that cooperation between governments can be beneficial when financial stability is shared across countries. Their analysis shows that without financial stability, there is no guarantee that at least one country gains from cooperation while no country loses. This may limit the 
willingness of countries to stick to the agreement when a crisis actually happens. However, they argued that the willingness of policy-makers to agree in advance on institutions for crisis management and sharing rules for the costs of future interventions is also limited because of concerns related to 'moral hazard'.

\section{Countries Joint Policy}

Meyer (2002), stated that two countries can both be better off if they take policy decisions jointly - with concern for the welfare of both rather than each pursuing its own goals independently. Ghosh and Masson (1994) go on to show that the gains from coordination accrue when it is the transmission effects of policy, not their domestic effects, that are uncertain.

\section{The Importance Of Guiding Principles (Oecd, 2010)}

OECD (2010), mentioned that the guiding principles are necessarily designed to assist States and all relevant actors including private and public, national and international financial institutions, bilateral lenders and organized groups of bondholders in the conduct of their respective activities and pursuit of their respective interests relating to external debt. These principles apply to the lending and borrowing decisions of States and other actors such as international financial institutions and private institutions as appropriate, the negotiation and execution of loan agreements or other debt instruments, the utilization of external loan funds, debtrepayments, the renegotiation and restructuring of external debt, the provision of debt relief when appropriate and to all policies, strategies and activities related thereto. The principles recognize the contingent liabilities which can arise for a State from external borrowing and lending between private actors. For the purposes of these principles, external (or foreign debt) refers to an obligation (including monetary obligation) created under a contractual agreement and owed by a State to a non-resident lender which may either be an international financial institution, a bilateral or multilateral lender, a private financial institution or a bondholder, or is 
subject to foreign law. It includes: (i) loans, that is, advances of funds to the debtor by the lender on the basis of an undertaking that the borrower will repay the funds at some future point (including deposits, bonds, debentures, commercial loans and buyer'scredits); and (ii) suppliers' credits, that is, contracts whereby the supplier allows the customer to defer payment until some time after the date on which the goods are delivered or the services are provided. The aggregate of a State's outstanding external debts is referred to as its external debt stock. These principles reflect and are consistent with international human rights standards. They apply existing human rights standards as they pertain to problems orissues occasioned by the external indebtedness of States and related policies.

\section{Guiding Principles For Cross-Border Cooperation On Crisis Management (Fsb, 2009)}

Financial Stability Board (2009), recommended the importance of providing the principles for Cross-border Cooperation on Crisis Management. Through these principles, relevant authorities, including supervisory agencies, central banks, and finance ministries, commit to cooperate both in making advance preparations for dealing with financial crises and in managing them. The principles also commit national authorities from relevant countries to meet regularly alongside core supervisory colleges to consider together the specific issues and barriers to coordinated action that may arise in handling severe stress at specific firms, to share information where necessary and possible, and to ensure that firms develop adequate contingency plans.

In different perspectives, Lumina (2011) in his article " Guiding principles on foreign debt and human rights (United Nations General Assembly), recommended that the issue of foreign debt and its impact on human rights and development, particularly in developing countries, has preoccupied the international community for more than three decades and although a number of official initiatives to address it have been implemented over the years, these have failed to deliver an equitable 
and enduring solution in line with the political commitments reflected in various resolutions and declarations, notably the Millennium Declaration and the Monterrey Consensus of the International Conference on Financing for Development. Moreover, the debt of these countries has continued to grow and to constrain not only their development prospects but also to undermine their capacity to establish the conditions for the realization of human rights, particularly economic, social and cultural rights.

Lumina (2011), argued that national development strategy should be countryowned and should contain development goals that are responsive to the needs of the people who are the ultimate beneficiaries of development. Such goals should be agreed through a meaningful and participatoryconsultation process involving all stakeholders, especially civil society organizations. Besides, he stated that country ownership of national development strategiesis the foundation of development effectiveness. It implies that national governments should have the ability to freely choose the strategies which they design and implement, and take the lead in both policy formulation and implementation.

In order to understand a more detail explanation about the clear requirements for States to cooperate with and assist each other in achieving certain goals, including ensuring development and eliminating obstacles to development, the writer cited a number of factors from some clausules of the United Nations Charter (2011), that need to be considered as the guding principles when making international cooperation among others as follows : (i) mitigating the impact of international financial cooperation, (ii) rights and obligations in external debt agreements, (iii) minimum core obligations, (iv) responsibilities of international cooperation among states, (v) the shared responsibility of debtors and creditors, (vi) ensuring an independent process of national development,(vii) transparency, participation and accountability, (viii) general legal and institutional framework, (ix) decision to borrow or to lend, (x) loan negotiation and contracting, (xi) legal authority to contract, (xii) use of loan funds, (xiii) debt servicing orrepayment, (xiv) 
renegotiation and restructuring, (xv) debt relief, (xvi) debt moratorium, (xvii) sharing risks of the loan, (xviii) sale of debt in the secondary market, (xix) debt sustainability assesment, (xx) public audits of debt and lending portfolios, (xxi) contingent liabilities, and (xxii) allignment to national development goals.

\section{Indonesia Case}

Related to International Financial Cooperation, some Indonesian experienced are expounded below which can be used as a lesson learned in order to provide a clearer insight for the readers about the discrepancies between the existing conditions and the futurechalenges of International Financial Cooperation as follows:

When Indonesia was under the economic crisis during the period of 1997/1998, IMF suggested that Indonesia should raise up its interest rates up to $70 \%$ by reasoning of avoiding capital outflow. It was true that this policyhad been successful in pressuring the inflation rate. Hoever, this policy was unable to recover the Indonesian economy as a whole. Meanwile, the real sector was geting worst. Another unfavourable problemencountered by Indonesia during that economic crisis when Indonesia intended to initiate the formation of CBS (Currency Board System or Fixed Exchange Rate System), this policy was rejected by the IMF (Cirillus, 2004).

Based on the political and economic point of view, the risky prescription for political and economic stability is the execution of fiscal tightening and budget reduction. For instances, during the crisis where the people's purchasing power is declining, whilst at the same time IMF demanded Indonesian government to reduce the oil and electricity subsidy. According to the pure economic analysis, it can be correct, but not from polical economic insight, especially when the time frame of its implementation is not persisted. Following, the reduction of oil and electricity, there social riots took place in Jakarta in mid 1998. 
Another crucial policy pursued by the IMF was about its recommendation to launch the deregulation and privatization policies on the Indonesian econmomy during the crisis. The reasons of IMF were to improve eficiency and competitiveness. In fact, these polices have caused the overtaking off the share ownership of Indonesian State Entrprises by the foreigners who have higher purchasing power compare to Indonesian investors. This phenomenon had worsen the Indonesian economy. In that period, the IMF have also recommended to liquidate 16 Indonesian Banks, to reduce import tax of sugar and rice, and also to abolish the prohibition of wooden logs export.

\section{Further Insight Of Developing Countries Cases}

\begin{tabular}{|c|c|c|c|c|}
\hline Country & $\begin{array}{l}\text { World Bank } \\
\text { Loan }\end{array}$ & $\begin{array}{c}\text { Privatisation } \\
\text { Condition }\end{array}$ & $\begin{array}{l}\text { IMF } \\
\text { Loan }\end{array}$ & $\begin{array}{c}\text { Privatisation } \\
\text { Condition }\end{array}$ \\
\hline Bangladesh & $\begin{array}{l}\text { Development } \\
\text { support } \\
\text { credit III } \\
(2005)\end{array}$ & $\begin{array}{l}\text { Bring Rupali Bank to } \\
\text { the point of } \\
\text { divestment by Dec } \\
\text { 2004; (Prior Action) }\end{array}$ & $\begin{array}{l}\text { Third } \\
\text { Review } \\
\text { under } \\
\text { the } \\
\text { PRGF } \\
(2005)\end{array}$ & $\begin{array}{l}\text { Bring Rupali } \\
\text { (Bangladesh Bank) to } \\
\text { point of sale } \\
\text { (Benchmark \& Prior } \\
\text { Action) }\end{array}$ \\
\hline Ethiopia & $\begin{array}{l}\text { Second } \\
\text { poverty } \\
\text { reduction } \\
\text { support } \\
\text { credit }(2004)\end{array}$ & $\begin{array}{l}\text { Continue satisfactory } \\
\text { implementation of } \\
\text { CBE (Commercial } \\
\text { Bank of Ethiopia) } \\
\text { restructuring plan } \\
\text { (Benchmark) }\end{array}$ & $\begin{array}{l}\text { Sixth } \\
\text { Review } \\
\text { under } \\
\text { the } \\
\text { PRGF } \\
(2005)\end{array}$ & $\begin{array}{l}\text { Finalisation of } \\
\text { restructuring plan } \\
\text { for the National } \\
\text { Bank Ethiopia } \\
\text { (Benchmark) }\end{array}$ \\
\hline Ethiopia & $\begin{array}{l}\text { Second } \\
\text { poverty } \\
\text { reduction } \\
\text { support } \\
\text { credit (2004) }\end{array}$ & $\begin{array}{l}\text { Offer for sale } \\
\text { Commercial Bank of } \\
\text { Ethiopia, including } \\
\text { preparation of bid } \\
\text { documents and } \\
\text { issuing the invitation } \\
\text { for bids } \\
\text { (benchmarks) }\end{array}$ & $\begin{array}{l}\text { Sixth } \\
\text { Review } \\
\text { under } \\
\text { the } \\
\text { PRGF } \\
(2005)\end{array}$ & $\begin{array}{l}\text { Finalisation the } \\
\text { adoption of a } \\
\text { financial } \\
\text { restructuring plan by } \\
\text { the goverment for } \\
\text { the Commercial } \\
\text { Bank of Ethiopia } \\
\text { (Performance } \\
\text { Criteria) }\end{array}$ \\
\hline Ghana & $\begin{array}{l}\text { Third } \\
\text { poverty } \\
\text { reduction }\end{array}$ & $\begin{array}{l}\text { Electricity: maintain } \\
\text { implementation of } \\
\text { tariff adjustment }\end{array}$ & $\begin{array}{l}\text { Third } \\
\text { Review } \\
\text { under }\end{array}$ & $\begin{array}{l}\text { Ensure electricity } \\
\text { and water tarrifs are } \\
\text { in line with their }\end{array}$ \\
\hline
\end{tabular}




\begin{tabular}{|c|c|c|c|c|}
\hline Country & $\begin{array}{c}\text { World Bank } \\
\text { Loan }\end{array}$ & $\begin{array}{c}\text { Privatisation } \\
\text { Condition } \\
\end{array}$ & $\begin{array}{l}\text { IMF } \\
\text { Loan }\end{array}$ & $\begin{array}{c}\text { Privatisation } \\
\text { Condition } \\
\end{array}$ \\
\hline & $\begin{array}{l}\text { support } \\
\text { credit (2005) }\end{array}$ & $\begin{array}{l}\text { mechanism } \\
\text { (Benchmark) }\end{array}$ & $\begin{array}{l}\text { the } \\
\text { PRGF } \\
\text { (2005) }\end{array}$ & $\begin{array}{l}\text { respective formulas } \\
\text { for automatic } \\
\text { quarterly adjusments } \\
\text { (Privatisation } \\
\text { Associated Reform } \\
\text { Performance } \\
\text { Criteria) }\end{array}$ \\
\hline Mali & $\begin{array}{l}\text { Public } \\
\text { Finance } \\
\text { Management } \\
\text { Credit (2005) }\end{array}$ & $\begin{array}{l}\text { Agree on the } \\
\text { privitation for the } \\
\text { Inter-Bank of Mali } \\
\text { (Benchmark) }\end{array}$ & $\begin{array}{l}\text { Sixth } \\
\text { Review } \\
\text { under } \\
\text { the } \\
\text { PRGF } \\
(2005)\end{array}$ & $\begin{array}{l}\text { Tender for Sale of } \\
\text { Goverment Stake in } \\
\text { Inter-Bank of Mali } \\
\text { (Benchmark) }\end{array}$ \\
\hline Nicaragua & $\begin{array}{l}\text { Poverty } \\
\text { Reduction } \\
\text { Support } \\
\text { Credit (2003) }\end{array}$ & $\begin{array}{l}\text { Sale of } 49 \% \text { of the } \\
\text { Nicaraguan } \\
\text { Goverment's shares } \\
\text { of ENITEL } \\
\text { (telecomunications } \\
\text { company) has been } \\
\text { initiated; sale of } 49 \% \\
\text { of ENITEL's shares } \\
\text { concluded } \\
\text { (Benchmark) }\end{array}$ & $\begin{array}{l}\text { Fifth \& } \\
\text { Sixth } \\
\text { Review } \\
\text { of the } \\
\text { PRGF } \\
(2006)\end{array}$ & $\begin{array}{l}\text { Divest the remaining } \\
\text { goverment stake in } \\
\text { ENITEL } \\
\text { (telecomunications } \\
\text { company) } \\
\text { (Benchmark) }\end{array}$ \\
\hline
\end{tabular}

World Bank and IMF conditionality: a development injustice, Eurodad, June 2006

The above cases showed that the World Bank and IMF who have a lot of experiences in managing the modern and well developed economic should actually have known the institutional problems, market conditions, law enforcement and bureaucracy barriers of the developing countries. Hence, it should have given sufficient guidances or advices for its member countries who are expecting its assistances. As a matter of fact, the foreign loan which is provided by the World Bank is still a big burden for the developing countries up to the recent years as it can be seen above. 


\section{ANALYSIS}

International Financial Cooperation today may require more complex preparation than ever, particularly in the era of globalization. It is known that the global economy has surpassed domestic circumstances among nations which consequently lead to the need of preparing an advance international financial cooperation principles in line with the changing socio-economic, cultural and political condition of the world. Regardless to these changing circumstances, the international financial cooperation may differ in nature, depends on the types of the financial institution involved and the objective of the cooperation, while the literature on international policy coordination is vast and multifaceted (there is no one size fits for all). However, there are some basic conditions that can be shared in common. The writer observation based on various literatures found that the universalities of the international financial cooperation can be seen as follows :

There are two central aspects of international financial cooperation that must be taken into consideration: (1) the optimalstructure of international financial cooperation which can perfectly provideoptimum advantages for domestic circumstances, and (2) the pattern of compliance with international cooperation agreements which determines commitment levels, avoiding consequences of violation/risks, and high quality of monitoring capability. (Svolix, 2014).Studies by Freixas., et al (2011), showed that without financial stability, there is no guarantee that at least one country gains from cooperation while no country loses. This may limit the willingness of countries to stick to the agreement when a crisis actually happens. However, they argued that the willingness of policy-makers to agree in advance on institutions for crisis management and sharing rules for the costs of future interventions is also limited because of concerns related to 'moral hazard'

The failure of major economies and global institutions to recognize and address the global governance issues can be seen from the World Bank data (2012) which potrayed that the total external debt of emerging and developing economies rose from US\$2,678.4 billion in 2003 to US\$5,414.6 billion in 2010 and is projected to 
rise to US\$6,446.3 billion in 2012.3 Debt service payments rose from US\$795.2 billion in 2003 to US $\$ 1,743.7$ billion in 2010, and were projected to rise to US $\$ 2,010.8$ billion and US\$2,265.5 billion in 2011 and 2012 respectively. In 2003, the total external debt of the Heavily Indebted Poor Countries (HIPCs) - those countries whose debts are deemed "unsustainable" by the International Monetary Fund (IMF) and World Bank - was US $\$ 172$ billion. In 2010, it decreased marginally to US\$147.9 billion, ostensibly due to international debt relief. However, it was projected to rise to US $\$ 163.3$ billion in 2011 and US\$178 billion in 2012 largely as a consequence of new loans taken out to mitigate the impacts of the global financial crisis. Additionally, as recent events in Europe suggest, debt problems are not the exclusive preserve of developing countries.The above facts can be used as a strong conviction for every nation state that the international financial cooperation model needs to be reformed. In order not to make the same mistakes in the future, the international financial cooperation should avoid the overwhelming dominance of developed countries over the developing countries in designing their cooperation. Instead, an international financial cooperation should emphasize upon the importance of fairness, equality and justice which ensure the optimum goals of the financial cooperation among the countries involved. In other words, no one country is allowed to dominate the others.

The over ruling of international financial cooperation such as in the case of a conditional of debt relief upon the loan provided such as the implementation of policies of privatization, trade liberalization, investment deregulation or financial sector liberalization related to debt relief, creditors should no longer imposed on the debtor countries. Conversely, under the occasion of indebtedness, the creditor should respect the debtor's State's independent process to freely choose the strategies which they design and implement, and take the lead in both policy formulation and implementation. In other words, it can be said that a national development strategy should be country-owned and should contain development goals that are responsive to the needs of the people who are the ultimate 
beneficiaries of development. Such goals should be agreed through a meaningful and participatoryconsultation process involving all stakeholders, especially civil society organizations. It is apparent, that Country ownership of national development strategiesis the foundation of development effectiveness. It is essential to underline that Country ownership of national development strategies is the foundation of development effectiveness. It implies that national governments should have the ability to freely choose the strategies which they design and implement, and take the lead in both policy formulation and implementation.Furthermore, any such economic, financial or technical advice, instruction, guidance or similar recommendation should be exclusively aimed towards restoring a debtor State's economic viability and growth, and thus its ability to repay its external debts without sacrificing its ability to perform its international human rights obligations. Other objectives that are remotely or tangentially connected with this aim should be avoided. Whenever such policies are deemed necessary by a debtor State, adequate social security measures to mitigate the adverse impact thereof, especially on vulnerable or marginalized groups, must be put in place.

More importantly, under an international financial cooperation, creditor States and the international financial institutions must not take advantage of an economic, financial or external debt-related crisis as an opportunity to push for structural reforms in debtor States, however useful such reforms might be perceived to be in the long term. Such reforms should be initiated, formulated and implemented by the debtor States themselves, if they deem appropriate, in pursuance of an independent process of national development. It can be said, that international financial cooperation must beconsistent with country-designed development strategies.

It should be noted, that when one country arranged a loan agreement, the success of the agreement will be depending on a variety of factors, such as responsible lending and borrowing, the loan terms and conditions, prudent use of loans and proper debt management, debt financing that cancontribute to countries' 
economic development and the establishment of conditions for the realization of human rights. Nonetheless, empirical evidence shows that in many of the poorest countries the fulfillment of debt service obligations is often undertaken at the expense of social investment, including investment in services that contribute to the realization of human rights. In addition, excessive debt service burdens and harmful conditions linked to loans and debt relief often limit investment in and undermine the provision of accessible public services. Apart from undermining obligations on economic, social and cultural rights, excessive debt burdens pose major obstacles for some countries in achieving the Millennium Development Goals. Therefore, in order to avoid an excessive debt burden, the creditors and debtors should share responsibility for preventing and resolving unsustainable debt situations, and both parties need to ensure that funds will not be used for non-public purposes or for a non-viable project.In the case of international financial cooperation is related to lending and borrowing, it can be stated that any debtor states experienced difficulty in repaying their external debts, the debtor states should have a right to renegotiate these to creditors with the aim of reaching a restructuring agreement that enables the debtor state to service its external debts without compromising its capacity to fulfill its international human rights obligations or implement its development goals. The renegotiation and restructuring should be conducted in good faith and should cover all types of external debts owed to all types of external creditors, including international financial institutions. Then, for the heavily indebted countries, the alleviation of debt and debt service burdens should be made possible through debt relief efforts such as debt forgiveness, debt rescheduling, debt service reduction and interest moratorium. Again, it is important to note that debt relief efforts must not compromise the provision of basic services. In particular, debt relief conditions that may adversely impact the realization of human rights or undermine development in the beneficiary State must be avoided, and financing from debt relief mustneither replace official development assistance nor be considered as such. By the time, when there is a change in circumstances beyond the control of the 
Borrower State arises, the parties should negotiate and agree on a moratorium on debt repayment. Such a moratorium should apply to the principal, interest, commission and penalties and should apply throughout negotiations on debt restructuring.Another crucial aspect of international financial cooperation is supposed to be about sharing risk of the loan which often caused by the fluctuation of exchange rate. As such, lenders should offer the possibility of denominating all or part of the loan in the Borrower State's local currency, or the lenders and borrowers should have an advance agreement to avoid exchange rate risks through forward contract negotiation (hedging mechanism). Besides, in order to help balance output or trade risk, lenders should offer the possibility of indexing loan repayments to rates of economic and/or export growth of the debtor's countries.

When there is any disputes between parties involved in international financial cooperation, the disputes must be resolved by an independent mechanism. In this regard, States and all relevant actors including international financial institutions, bilateral or multilateral lenders and private financial institutions should consider the establishment of an international debt workout mechanism to restructure unsustainable debts and resolve debt disputes in a fair, transparent, efficient and timely manner. The main aim of such a mechanism is to ensure that debtor States can achieve economic viability and growth, and restore their capacity to service their external debts without compromising the fulfillment of their international human rights obligations. The establishment and operation of such a mechanism should be guided by the foundational principles $\mathrm{s}$ as well as the following specific considerations: (a) The international debt restructuring mechanism should be independent of creditors and debtors; (b) The assessment of the debtor State's economic or financial situation shouldbe made by a neutral body; (c) The mechanism should ensure that a debtor State, during and after the restructuring process should be able to fulfil its international human rights obligations, implement its development programme and provide basic services to all persons living in its territory and under its jurisdiction; (d) The mechanism should have the mandate to 
rule on the alleged "odiousness" or "illegitimacy" of particular external debts.Finally, it is understood that international financial cooperation is always related to the project financing as it has been illustrated in the Indonesian case study above. In order to ensure the effectiveness of the cooperation in project financing, it is necessary to ensure that the international treaty which binding the project financing shall cover, among others, the following areas : (1) implementation of project strategies and policies and development/elaboration of forecasts, scenarios, as well as improvement of the statistical recording system in theproject based on timely exchange of information in accordance with international practices, as well as infrastructure developments, (2) establishing effective mechanisms to address potential crisis situations in a spirit of solidarity, (3) modernization and enhancement of existing project infrastructures of common interests, including project capacities, safety and security. (4) The regulatory cooperation shall take into account the need to ensure relevant public service obligations, including measures to inform and protect customers from unfair selling practices, and the project should provide wide access for the benefit of the public.

\section{CONCLUSION AND POLICY RECOMMENDATION}

\section{Conclusion}

International financial cooperation may differ in nature, depends on the types of the financial institution involved and the objective of the cooperation (there is no one size fits for all). However, there are some basic conditions that can be shared in common. Based on the study of various literatures, it is found that the challenges of international financial cooperation today may encircle not only about the readiness of the nation states, institutions, and projects in utilizing the financial cooperation, but it may also include an optimal structure of cooperation agreement which can perfectly provide optimum advantages for domestic circumstances. 
To achieve such objectives, the international financial cooperation model needs to be reformed. In order not to make the same mistakes in the future, the international financial cooperation should avoid the overwhelming dominance of developed countries over the developing countries in designing their cooperation. Instead, an international financial cooperation should emphasize upon the importance of fairness, equality and justice which ensure the optimum goals of the financial cooperation among the countries involved. The over ruling of international financial cooperation such as in the case of a conditional of debt relief upon the loan provided such as the implementationof policies of privatization, trade liberalization, investment deregulation or financial sector liberalization related to debt relief Creditors should no longer imposed on the debtor countries.

When the international financial cooperation is related to lending and borrowing agreement, it should be noted that any such economic, financial or technical advice, instruction, guidance or similar recommendation should be exclusively aimed towards restoring a debtor State's economic viability and growth, and thus its ability to repay its external debts without sacrificing its ability to perform its international human rights obligations. Other objectives that are remotely or tangentially connected with this aim should be avoided. Whenever such policies are deemed necessary by a debtor State, adequate social security measures to mitigate the adverse impact thereof, especially on vulnerable or marginalized groups, must be put in place.

More importantly, under an international financial cooperation, creditor States and the international financial institutions must not take advantage of an economic, financial or external debt-related crisis as an opportunity to push for structural reforms in debtor states, however useful such reforms might be perceived to be in the long term. Such reforms should be initiated, formulated and implemented by the debtor States themselves, if they deem appropriate, in pursuance of an independent process of national development. It can be said, that international financial cooperation must beconsistent with country-designed development strategies. 
Another crucial aspect of financial cooperation is supposed to be about sharing risk of the loan which often caused by the fluctuation of exchange rate. As such, lenders should offer the possibility of denominating all or part of the loan in the Borrower State's local currency, or the lenders and borrowers should have an advance agreement to avoid exchange rate risks through forward contract negotiation (hedging mechanism). Besides, in order to help balance output or trade risk, lenders should offer the possibility of indexing loan repayments to rates of economic and/or export growth of the debtor's countries.

It is understood that international financial cooperation may be related to the project financing as it has been illustrated in the case study above. In order to ensure the effectiveness of the cooperation in project financing, it is necessary to ensure that the international agreement which binding the project financing need to establish effective mechanisms to address potential crisis situations in a spirit of solidarity, and the project should provide wide access for the benefit of the public.

Finally, it can be stated that if the central part of achieving the optimal international financial cooperation is depent on the willingness of the member states involved to consider the domestic interests and the inherent risks of the cooperation. Besides, no countries in the international financial cooperation is allowed to dominate the other member states if the success of long-run cooperation want to achieve optimally.

\section{Policy Recommendation}

1. An international financial cooperation agreement between governments thatcannot perfectly observe their domestic circumstances reconciles a trade-off between political efficiency of international cooperation and incentives to misrepresent domesticcircumstances. Therefore, the domestic circumstances should be well understood before undertaking an international financial cooperation in order to ensure that the internationalfinancial cooperation provide optimum advantages for domestic circumstances. 
2. An international financial cooperation should emphasize the importance of providing the principles for Cross-border Cooperation on Crisis Management. Through the seprinciples, relevan tauthorities, including supervisory agencies, central banks, and finance ministries, commit to cooperate both in making advance preparations for dealing with financial crises and in managing them proportionately.

3. Without financial stability, there is no guarantee that at least one country gains from cooperation while no country loses. This may limit the willingness of countries to stick to the agreement when a crisis actually happens. Therefore, policy-makers need to agree in advance on institutions for crisis management and sharing rules for the costs of future interventions in the case of crisis.

4. The States involved in international financial cooperation are obliged to achieve progressively the full realization of economic, social and cultural rights requires States to move as expeditiously and effectively as possible towards the full realization of these rights.

5. The availability of guiding principles is of utmost important in international financial cooperation. The guiding principles should be designed to assist States and all relevant actors including private and public, national and international financial institutions, bilateral lenders and organized groups of bondholders in the conduct of their respective activities and pursuit of their respective interests relating to external debt.

6. Excessive debt service burdens and harmful conditions linked to loans and debt relief often limit investment in and undermine the provision of accessible public services. Apart from undermining obligations on economic, social and cultural rights, excessive debt burdens pose major obstacles for some countries in achieving the Millennium Development Goals.

7. The International Financial Institution such as World Bank and IMF should be able to provide appropriate policies in accordance with the real need and 
condition of the developing countries being assisted to ensure that theproposed program can be implemented.

8. Itis essentialto underline that Country ownership ofnational development strategies is the foundation of developmenteffectiveness. It implies that national governments should have the ability to freely choose the strategies which they design and implement, and take the lead in both policy formulation and implementation.

\section{REFERENCE}

Bernes,T.A.(2012). Strengthening International Financial Institutions toPromote Effective International Cooperation. Canada: CIGI's.

Cyrillus, H: Penanganan Krisis dan Indonesia Pasca IMF. Jakarta: Gramedia Pustaka Utama, 2004. hal 93.

Deliarnov, Ekonomi Politik, Jakarta: Erlangga, 2006, hal.178.

Financial Stability Board (FSB) (2013), Thematic ReviewonRisk

Governance, Freixas., et al. (2011). Beneficial Cooperation Between Government.

Niepman, F and Eisenlohr, T.S. (2011). Finding the right balance between efficiency, gains, the preservation of national sovereignty, and optimal internasional cooperation remains a challenging task.

FSB (2009). Principles for Cross-border Cooperation on Crisis Management. (Policy Documents).

Hadiwinata, B.S. Politik Bisnis Internasional,Yogyakarta: Kanisius, 2002, hal. 183.

Hale, T., et al. (2013). Gridlock: the growing breakdown of global cooperation London: Oxford University.

Hutagalung, (2009). Peran Bank Dunia dan IMF dalam Perekonomian Indonesia Dulu dan Sekarang. Di dalam: Abimanyu,

A. Megantara. 2009. Era Baru Kebijakan Fiskal: Pemikiran, Konsep, dan Implementasi. PT Kompas Media

Ibrahim, A. (2011). Peran IMF Dalam Menangani Krisis Ekonomi di Indonesia. Kompasiana.

Krugman, P. (1994), The failure of IMF in assisting its member countries.

Lumina, C. (2011). Guiding principles on foreign debt and human rights. United Nation General Assembly.

Svolik, M. (2004). Political Service Department University of Chicago.

OECD. (2010). Corporate Governance and the Financial Crisis: Effective implementation of risk management.

Sachs (2003). The IMF's Role in Low IncomeCountries: Issues and Challenges. (IMF'sWorking Paper). 
Vol 9, No 1 Maret 2018

Rachbini, Didiek J. 2001.Tanggung JawabBank Dunia. Agrimedia Volume 7Nomor 1.

Stiglitz, J.E. (2002). Globalization and ItsContents. (W.W.Norton, NewYorkand London).

The IMF at a Glance (2015).The International Monetary Fund (IMF) promotes international financial stability and monetary cooperation. 